\section{God bok om stress på jobben}

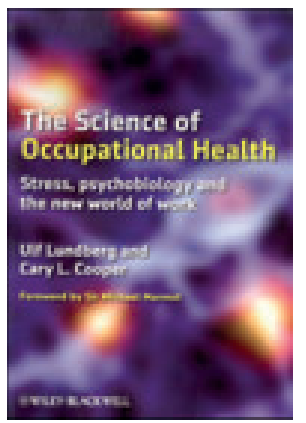

\author{
Ulf Lundberg, Cary L.Cooper, \\ The science of occupational health \\ Stress, psychobiology and the new world of \\ work. 167 s, ill. Chichester: Wiley-Blackwell, \\ 2011. Pris GBP 35 \\ ISBN 978-1-4051-9914-8
}

Forfatterne har lang erfaring som forskere på stressrelaterte helseproblemer i arbeidslivet. Begge er psykologer med spesiell interesse for sammenhengen mellom psykologi og biologi. Boken er en lettlest gjennomgang av eldre og nyere psykobiologisk forskning med relevans for arbeidshelse. Arbeidslivet har endret seg dramatisk bare på de siste hundre årene. Samtidig er vi biologisk sett de samme som for hundre tusen år siden. Hvordan tilpasser vi oss?

Det gamle arbeidslivet var preget av primærnæringene og industrien. Det lever videre, og mange steder i verden er skader og fysisk overbelastning fortsatt de største utfordringene. I vår del av verden gjelder dette stadig færre yrker. For oss er det et større problem at eksponeringen for internasjonal konkurranse får mange til å tro at arbeidervernet er en gammeldags bremsekloss i «det moderne arbeidsliv». Det ropes på «fleksibilitet» - skiftende arbeidstid, skiftende arbeidsoppgaver, maksimal produktivitet og minimal trygghet. Men menneskene som skal delta i arbeidslivet er ikke ubegrenset fleksible og tilpasningsdyktige. Resultatet kan være at svært mange unge ikke slipper inn i arbeidslivet i det hele tatt og at de som er sluppet inn ikke henger med, men må gi opp lenge før forventet pensjonsalder. De fleste har erfart at mental og fysisk helse blir påvirket av utrygge arbeidsforhold. Boken gir oppdatert kunnskap om mekanismene bak helseproblemene.

For bedriftsleger og andre som vil overtale arbeidslivets ledere til å prioritere arbeidshelse høyere, kan denne boken være til god hjelp. Den forteller med eksempler fra forskning og praksis hvordan arbeidsorganisasjonen kan stimulere til innsats og god helse, men også skape negativ stress, helseproblemer og lav produktivitet. Det er ikke bare dem som står lavest på stigen som er utsatt. Også ledere opplever utrygghet og svekket motivasjon $i$ et arbeidsliv preget av stadig nedbemanning, omorganisering og konkurranseutsetting.

Boken bygger på flere tiårs forskningstradisjon, ikke minst fra Sverige. Det gjør den høyst relevant også for norske lesere. En del av de helsefremmende prinsippene som forfatterne anbefaler ble skrevet inn i den norske arbeidsmiljøloven alt ved revisjonen i 1977, slik som arbeidstakers rett til medvirkning, innflytelse og forutsigbarhet. Boken gjør det så å si biologisk forståelig hvorfor denne reguleringen av arbeidslivet, sammen med en sosialpolitikk som prioriterte økonomisk trygghet ved sykdom og arbeidsløshet, har vært viktig for norsk folkehelse.

\section{Ebba Wergeland}

Arbeidstilsynet i Oslo

\section{Positiv psykologi}

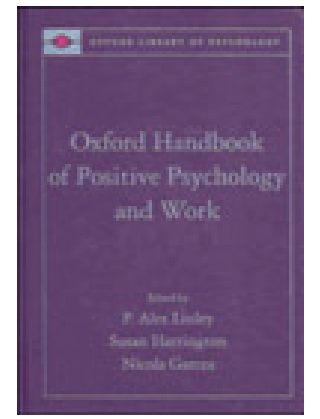

P. Alex Linley, Susan Harrington,

Nicola Garcea, red.

Oxford handbook of positive psychology and work

343 s, tab, ill. Oxford: Oxford University Press,

2010. Pris GBP 50

ISBN-978-0-19-533544-6

Positiv psykologi er en viktig trend innen populærpsykologien. Martin Seligman, som ble kjent for begrepet «lært hjelpeløshet» og kritisert for å trekke altfor vidtrekkende konklusjoner fra dyreforsøk, får mye av æren for begrepet. Hans Learned optimism var en bestselger (1).

Positiv psykologi dreier seg om det som gjør at individene fungerer godt, er optimistiske, tilfredse og lykkelige. Tilhengerne hevder at psykologien tidligere har fokusert utelukkende på symptomer og atferd forbundet med psykiske problemer og psykiatri. Dette er nok ikke helt korrekt her i Skandinavia, hvor mange kliniske psykologer har argumentert for vektlegging av pasientenes ressurser, mens psykiatere har fokusert på diagnoser og behandling. Normal psykologi er ikke noe nytt. Men kunnskap om hva som bedrer funksjonsevne, tilfredshet og kanskje lykke, må være viktig. Dessverre er positiv psykologi preget av slagord som «lykke er ikke bare å unngå det som er galt, men også å oppdage det som er riktig» og «det umulige ble mulig ved at man inntok en overflodstilnærming til endringer i stedet for en mangeltilnærming, dvs. problemløsningstilnærming» (s. 4).

Oxford handbook of positive psychology and work skal belyse anvendelsen av positiv psykologi i virksomhetene. De 26 kapitlene er forfattet av konsulenter (konsulentfirmaer) og forskere fra psykologiske institutter ved «business schools» og universiteter. Mange av kapitlene er redegjørelse for konsulentfirmaets verktøypakke og noen av deres suksesshistorier. Mange av begrepene og modellene som presenteres er firmaenes versjon av nokså velkjente prinsipper.

I boken er det et meget interessant kapittel om utviklingen av holdninger og personlighet de siste 50 årene (Generation Me). Og flere av undersøkelsene til Gallup gir interessante perspektiver på holdninger. Men svært mye av det som beskrives er velkjente fenomener og faktorer i en innpakning. Eksempel: Det finnes mange tidligere studier av «involvement» definert som at man identifiserer seg med jobboppgaver, «commitment» definert som tilknytning til arbeidsplassen og om motivasjon. Mange positivpsykologer bruker begrepet «engagement» som en slags upresis sum av de tre veldefinerte faktorene.

Hvert kapittel har referanseliste. De aller fleste av referansene er til egne arbeider eller til andre positivpsykologer. For lesere med noe kjennskap til organisasjonspsykologi gir mange av kapitlene en «keiserens nye klær»-opplevelse. Man kan få et inntrykk av at konsulentene må fremstå som originale for å kunne selge sine varer. Boken omtaler en rekke spørreskjemaer og verktøy som konsultentfirmaene anvender for å utvikle fokus på positive sider. Boken er lite egnet som introduksjon til arbeids- og organisasjonspsykologi, fordi den har svak omgang med grunnleggende sosialpsykologi og hopper over presise definisjoner.

Det gis mange eksempler på at fokus på positive sider hos den enkelte og fokus på positiv tilbakemelding kan gi gunstige ringvirkninger og snøballeffekt. Det er nyttig å bli minnet om dette, selv om de fleste nå er klar over farene ved misnøyekulturer. Innen klinisk psykologi er man for lengst blitt oppmerksom på betydningen av tankemønstre (kognitive skjema) for utvikling inn og ut av psykiske problemer. Det er liten tvil om at det er gunstig å være optimistisk, 
ha (sunn) selvtillit og arbeide sammen med flinke folk. Men hva er seleksjon og hva er endringer som følge av tilnærmingen med positiv psykologi? Det får man ingen svar på.

Innen ledelsesforskningen finnes det begrenset empiri om gjennomføring av endringer. En hovedkritikk mot positiv psykologi som prinsipp for organisasjonsutvikling er empiriske undersøkelser der man har funnet at gjennomføring av endringer er vanskelig uten krise og kriseforståelse. Det finnes andre funn som indikerer at store endringer kan gjennomføres med stadige små forbedringer, men dette har vært basert på systematisk fokus på både mangler og muligheter. Toyota-modellen er eksempel på systematisk forbedringsarbeid som legger vekt på trinnvise, systematiske forbedringer av prosessene før positiv psykologi ble «funnet opp».

En hovedkritikk mot positiv psykologi generelt er at man overser at forbedringer ofte motiveres av opplevelsen av at noe ikke er godt nok. Hvis man ikke ser mangel eller feil, hvorfor skal man da endre noe? Det er hevdet at nettopp det at man ikke er helt fornøyd med egne prestasjoner er drivkraften som gjør at enkelte driver det langt. Det finnes mange eksempler på at virksomheter som var selvgode, er blitt akterutseilt.

En annen kritikk i denne sammenhengen er at positiv psykologi fokuser på enkeltindividet og den enkelte leder. Oxford handbook of positive psychology and work inneholder et par kapitler som omtaler gruppeinteraksjoner og team, men hovedfokus er på individene og ikke på organisatoriske forhold.

Positiv psykologi er blitt svært populært etter årtusenskiftet. Dette faller sammen med en periode med stor fokus på forskning om lykke og utallige selvhjelpsbøker om selvrealisering og selvutvikling. Veiledning av den enkelte leder er blitt en stor konsulentbransje.

Enkelte kapitler gir assosiasjoner til gamle kommunistiske propagandaskrifter. Når bare alle realiserer sitt potensial og ingen er negative, får vi paradis i virksomheten. Her er det mange gode poenger, men så lettvint er det ikke å realisere optimal trivsel, helse, produktivitet og inntjening.

\section{Stein Knardahl}

Statens arbeidsmiljøinstitutt

Oslo

\section{Litteratur}

1. Seligman MEP. Learned optimism. How to change your mind and your life. New York, NY: Pocket Books (Simon and Schuster), 1998

\section{Gammelmodig flyplasskrim}

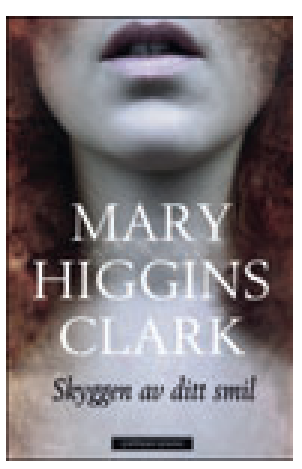

Mary Higgins Clark Skyggen av ditt smil

329 s. Oslo: Cappelen Damm, 2010

Pris NOK 369

ISBN 978-82-02-32587-9

Mary Higgins Clark (f. 1927) tilhører den lille, eksklusive gruppen kvinnelige krimforfattere som holder koken etter fylte 80 . Hun har skrevet imponerende 42 romaner og er oversatt til en rekke språk. Bøkene hennes er å finne på flyplasser verden over.

Av de andre nålevende «grand old ladies» er jeg vel kjent med P.D. James (f. 1920) og Ruth Rendell (f. 1930). Dette er mitt første møte med Higgins Clark. Og dessverre. Hvis jeg ikke skulle anmelde boken, ville møtet vært over på første side. Mer presist, etter 11 linjer. Hvorfor? Jo, for etter 11 linjer får en av bokens hovedpersoner beskjed av sin lege om at hun har to uker igjen å leve. I beste fall tre. Og en av mine regler for å dumpe en bok (eller film) er nettopp dette billige og forslitte dramaturgiske knepet: «Du har to uker igjen å leve». Alltid to. Eller tre. Uker eller måneder. Aldri fire eller fem eller åtte. Men plikten vant, jeg leste videre. Og konklusjonen? Etter 329 sider? Vel. Heretter stoler jeg blindt på egne regler.

Hva handler boken om? Kort fortalt: de slemme og de snille, skurker og helter. Når den gamle damen, Olivia Morrow, får dødsdommen av sin lege, utløses en samvittighetskonflikt. Hun sitter på en hemmelighet. Skal hun røpe den eller ta den med seg i graven? Konsekvensene er store og mange. Hemmeligheten er begravd i en bunke brev fra Olivias kusine, Cathrine. Disse avslører at Cathrine som 17-åring fikk et barn med den unge legestudenten, Alex Gannon. Barnet ble adoptert, Cathrine ble nonne og Alex en verdensberømt og styrtrik lege som utviklet medisinske patenter. Alex kom aldri over sin store kjærlighet, Cathrine. Formuen hans havnet hos to sleske nevøer - som er i ferd med å skusle den bort. Den rettmessige arvingen til Gannon-formuen er den unge barnelegen Monica, datter av den bortadopterte sønnen og Alex Gannons eneste barnebarn.

Alt dette vet Olivia Morrow. Og når hun får beskjed om at hun bare har to uker igjen å leve, lufter hun sine samvittighetskvaler for familielegen som serverte dødsdommen. Med dette utløses plottet. Og den drevne krimforfatteren kliner til. Higgins Clark kan sitt håndverk. Og skusler ikke med virkemidlene. Her er store og små skurker, villige til å gå over lik. Skurkene ser ut som skurker og de oppfører seg som skurker. Her er de edle og ranke. Den eiegode (og vakre) barnelegen, Monica, som fortjener både den ukjente bestefarens formue og den dyktige (og råkjekke) nevrokirurgens kjærlighet. Her er en ung jente som i dølgsmål fødte et barn og deretter tilbrakte livet i kloster. Som nonne grunnla hun barnesykehus og foretok mirakuløse helbredelser av barn med hjernesvulst og leukemi. Kandidat for kanonisering og helgenstatus. Men ikke hvis hemmeligheten blir kjent.

Higgins Clark er proff og historien er oppskriftsmessig skrudd sammen. Men det blir noe sjablongmessig ukebladaktig og gammelmodig over det hele. Handlingen foregår i nåtid, men verken e-post eller mobiltelefoner synes å være oppfunnet. Brev sendes i konvolutter med frimerke på. Og både helter og skurker venter uavlatelig på at fasttelefonen skal ringe.

Oversettelsen er grei, men med noen elementære blemmer. Refleksivt pronomen kan riktignok være kinkig, men bør beherskes av både oversetter og språkvasker. Det samme gjelder utilsiktede pleonasmer som «fatal dødsulykke». På godt norsk, smør på flesk.

Bokens tittel er direkte oversatt. Originaltittelen The shadow of your smile vil sikkert vekke assosiasjoner hos lesere som husker Love theme fra filmen The sandpiper (Het strand) (1965) med Elisabeth Taylor og Richard Burton. Senere har den levd videre, takket være Frank Sinatra, Shirley Bassey og Barbara Streisand for å nevne noen. Og rent personlig kunne jeg nok nøyd meg med musikkversjonen.

\author{
May Brit Lund \\ Lungeavdelingen \\ Oslo universitetssykehus, Rikshospitalet
}

